\title{
ORIGINAL SIN, PRETERITION, AND ITS IMPLICATIONS FOR EVANGELIZATION
}

\author{
EDUARDO J. ECHEVERRIA*
}

Sacred Heart Major Seminary

\begin{abstract}
In this paper, I examine the four elements-universal sinfulness, natural sinfulness, inherited sinfulness, and Adamic sinfulness - of the doctrine of original sin in both the Reformed confessions, with particular attention to the Canons of Dort, and the Council of Trent's definitive teaching on Original Sin. I give particular attention to the question regarding how all men are implicated in the sin of Adam. Realism and federalism will be analyzed as answers to this question. Even if a theological account is given that justifies the claim that God may justly impute Adam's sin to his posterity, that still leaves unanswered the question of unconditional negative reprobation, also called, preterition (praeteritio), namely, that God passes over some and not others. Does preterition jeopardize the Church's call to evangelization? That question will need to be reconsidered briefly, and in conclusion, in light of the doctrine of divine election and its implications for the preaching and hence proclamation of the gospel.
\end{abstract}

KEYWORDS: Original sin, preterition, realism, federalism, essential asymmetry

Nothing is better known than original sin for preaching; for understanding, nothing is more mysterious (Augustine 1966: 1, 22).

[T]here can be no doubt that nothing shocks our reason more than to say that the sin of the first man made guilty those who, so far from that source, seem incapable of having taken part in it. This contamination seems not only impossible to us, but also quite unjust.

Certainly, nothing shocks us more deeply than this doctrine. Nevertheless, without this most incomprehensible of all mysteries, we are incomprehensible to ourselves. Within this gnarled chasm lie the twists and turns of our condition. So, humanity is more inconceivable without this mystery than this mystery is conceivable to humanity (Pascal 1995: 42-43).

\section{Introduction}

At the April 2019 conference at Dort College, Sioux Center, Iowa, to commemorate the four hundredth anniversary of the Synod of Dort and its

* EDUARDO J. ECHEVERRIA (PhD 1981, Vrije Universiteit, Amsterdam) is Professor of Philosophy and Systematic Theology at Sacred Heart Major Seminary, Detroit. Email: echeverria.eduardo@shms.edu 
document, the Canons of Dort (hereafter CD), (Dennison 2014: 120-153), several key speakers presented the Canons as a missional document for a missionary church, sent by the Lord to proclaim the Gospel (Matt 28: 19-20). I understood the word missional to mean that the Canons, for instance, $C D$ 2.5, teach the kerygmatic universality (Berkouwer, 1955, 289; 1960, 240) of the gospel, meaning thereby that it should be proclaimed to all men, calling them all to repentance and conversion. It is a document calling the church to evangelization. 'Moreover, the promise of the gospel is that whosoever believes in Christ crucified shall not perish but have eternal life. This promise, together with the command to repent and believe, ought to be declared and published to all nations, and to all persons promiscuously and without distinction, to whom God out of His good pleasure sends the gospel.' Also relevant to this claim that the Canons teach kerygmatic universality is $C D$ 1.2: 'But in this the love of God was manifested, that He sent his only begotten Son into the world, that whomsoever believeth on him should not perish, but have eternal life (1 John 4:9; John 3:16)'. Furthermore, $C D 3 / 4.8$ states, 'As many as are called by the gospel are unfeignedly called. For God has most earnestly and truly declared in His Word what is acceptable to Him, namely, that those who are called should come unto Him. He also seriously promises rest of soul and eternal life to all who come to Him and believe'. The seriousness of preaching the calling of the gospel is underscored with the simultaneous emphasis that 'It is not the fault of the gospel, nor of Christ offered therein, nor of God who calls men by the gospel and confers upon them various gifts, that those who are called by the ministry of the Word refuse to come and be converted' $(C D$, $3 / 4,9$ ). All well and good, and orthodox.

Still, I protested this interpretation on several occasions at the conference because the Canons' alleged promotion of kerygmatic universality and hence the seriousness of preaching the gospel was at odds with, not to say endangered by, another aspect of the Canons, namely, its presupposition of unconditional negative reprobation $(C D 1.6,15)$. 'What peculiarly tends to illustrate and recommend to us the eternal and unmerited grace of election is the express testimony of sacred Scripture that not all, but some only, are elected, while others are passed by in the eternal decree.' This 'passing over' refers to preterition (praeteritio): the differentiation between those who are elected, while others are passed by, that proceeds from God's eternal decree. This decree is unconditional because God does not 'pass over' men because he foresees their sin and unbelief. But since they are not passed because of their sin, this raises the question regarding not only their moral responsibility for their preterition but also whether they can be held accountable for their failure to respond to the gospel since they did not receive the saving grace to respond. The same question regarding 'being passed over' and moral responsibility arise in section VII of chapter 3 of the Westminster Confession of 
Faith (1646): "The rest of mankind God was pleased, according to the unsearchable counsel of His own will, whereby He extendeth or withholdeth mercy, as He pleaseth, for the glory of His sovereign power over His creatures, to pass by; and to ordain them to dishonor and wrath for their sin, to the praises of His glorious justice (Matthew 11:25-26; Romans 9:17-18, 2122; 2 Timothy 2:19-20; Jude 4; 1 Peter 2:8)' (Dennison 2014: 239). Here, too, those men who are passed over are condemned because of their sin, but they are not passed over because of their sin. That would make reprobation conditional, contingent upon God foreseeing the sins of men. Why, then, does God save only some, passing over others? We do not know. All we hear repeatedly is that, in preterition, there is no injustice with God.

Still, we are left with a problem. Those whom God passes over by grace are incapable of responding to the gospel, and so how can they be blamed for not attaining salvation? Berkouwer is right: 'The demand to believe and repent goes out to everybody, but what a man who is considered to be rejected must believe becomes completely uncertain. For this man, standing in the glaring searchlight of the preaching [of the gospel], is not confronted with an invitation but with the reality of rejection. He can-in the light of this supposition-no longer be called upon to believe in Christ and salvation. There is no room left for the perspective of the Canons [of Dort], which relate the call to what is good in the sight of God, namely, that those who are called may come to Him' (Berkouwer 1955: 273; 1960: 228).

Nevertheless, $C D 1.1$ claims to justify preterition in view of original sin. The Romans 5 and 1 Corinthians passages are the loci classici of the original sin doctrine. This doctrine is a datum of revelation (Genesis 3). 'Therefore, just as sin came into the world through one man, and death through sin, and so death spread to all men, because all sinned' (Romans 5:12). 'For as in Adam all die, so also in Christ shall all be made alive' (1 Corinthians 15:22). I shall return particularly to Romans 5:12 below. For now, I note that this passage has been traditionally interpreted to mean that sin came into the world through one man, Adam, in whom all sinned. This interpretation of Romans $5: 12$ is taken to be the biblical basis for the following statement from the canons: 'As all men have sinned in Adam, lie under the curse, and are deserving of eternal death, God would have done no injustice by leaving them all to perish and delivering them over to condemnation on account of sin'. The claim here is that God's justice is paramount in his condemnation of men's sin, which is the sin of all men in and with Adam. Indeed, $C D 3 / 4$, Rejection of Errors, Paragraph 1, rejects what it considers an error: 'That it cannot properly be said that original sin in itself suffices to condemn the whole human race or to deserve temporal and eternal punishment'. (Dennison 2014: 149) The same point is alluded to in the concluding words of the Westminster Confession cited above. One other Reformed confession, the Belgic Confession, 
states the same about the justice of God in preterition. 'All Adam's descendants having thus fallen into perdition and ruin by the sin of Adam, God showed himself to be as he is: merciful and just. God is merciful in withdrawing and saving from this perdition those who, in the eternal and unchangeable divine counsel, have been elected and chosen in Jesus Christ our Lord by his pure goodness, without any consideration of their works. God is just in leaving the others in their ruin and fall into which they plunged themselves' (Dennison 2010: 433-434). God singles out some from the 'mass of perdition' leaving others condemned to an eternity of hell as the punishment of a sin 'for which they have ex hypothesi no personal responsibility whatever' (Williams 1927: 373). Thus, here, too, God's just judgment remains unexplained.

These claims about the just nature of God's judgment raise the question regarding the grounds of his indictment of all men. The answer to this question is the doctrine of original sin. It purports to account for the individual's involvement in Adam's sin and guilt prior to his personal self-involvement. How can the attribution of Adam's sin and guilt to me have the character of true sin and hence guilt? How can I acknowledge my own personal guilt in original sin? Here's the problem: how can one person be liable for another's guilt? What about my guilt, my sin, or peccatum proprium? Otto Weber explains:

The objections to the Church's dogma of original sin are, when taken as a whole, the expression of a self-understanding that centers in the concepts of freedom, responsibility and person. How can sin be regarded as a responsible and personal decision when the 'primal sin' (Luther) is precisely not that but discloses a situation for which I am charged in a completely hereronomous way (Weber 1995: 668).

Thus, isn't Adam's sin an alien guilt, a peccatum alienum, and so how can the guilt of his sin be our own guilt? As Berkouwer puts it: 'The guilt in which we are involved is always peccatum proprium or peccatum nostrum'. How then are we to understand the "relation between the "alienum" and the "proprium" peccatum?' (Berkouwer 1960: 215, 219; 1971: 432, 436). On this view, the justice of God's judgment on all men is traced back to the sin of Adam in whom humanity's sinfulness and guilt is justified as well as God's corresponding condemnation. But isn't it unjust for us to share Adam's guilt since only he actually committed the sin? How then is his sin and guilt transmitted to us?

In the following, I will examine the doctrine of original sin in the Reformed confessions (Berkouwer 1960: 253-260; 1971: 432, 436). I have in mind here the confessions of the Dutch-German Reformed tradition, represented by the Three Forms of Unity: the Belgic Confession of Faith (1561), the Heidelberg Catechism (1563), and the Canons of Dort (1618-1619). In addition, I also refer to the Scottish-English Reformed tradition: the Westminster Confession of Faith (1646-1647), and the Shorter and Larger Catechisms (1647). I also cite from the Swiss Reformed confessions, the Second Helvitic Confession 
(1566) and the Helvitic Consensus Formula (1675) (Beeke/Ferguson 2006: 4551). I give particular attention to the question regarding how all men are implicated in the sin of Adam. Realism and federalism will be analyzed as answers to this question.

The four elements of the doctrine of original sin discussed will serve as a backdrop to our consideration of the Council of Trent's definitive teaching on Original Sin promulgated in a decree on June 17, 1546 at the fifth session of this council (Canons 1511-1515). This decree reaffirms the Second Synod of Orange (530) but it also is the most comprehensive and definitive teaching on original sin issued by the Magisterium of the Church (Denzinger \$371372). The 1567 Catechism of the Council of Trent for Parish Priest reiterates that teaching in Article II. Indeed, the first universal catechism since Trent, namely, the Catechism of the Catholic Church (1992) extensively reiterates that teaching, §§386-421, and deepens our interpretation of it (see Grisez 1983: 333-359).

Furthermore, even if a theological account is given that justifies the claim that God may justly impute Adam's sin to his posterity that still leaves unanswered the question of preterition. That question will need to be reconsidered briefly, and in conclusion, in light of the doctrine of divine election and its implications for the preaching and hence proclamation of the gospel. Here, too, we consider the Canons of Dort, in particular, the Epilogue with its rejection of the equal symmetry of election and reprobation. It is probably the case that the Canons had in mind Canon 17 of the Decree on Justification of the Council of Trent, which rejects what is called predestinarianism: 'If anyone says that the grace of justification is given only to those who are predestined to life and that all the others who are called are called indeed but do not receive grace, as they are predestined to evil by the divine power, let him be anathema' (Denzinger §1567; see also, §333, 397, 627-628, 1556 Canon 6). It is in this context that we consider the question of preterition.

\section{Original Sin and the Reformed Confessions}

There are four elements to the doctrine of original sin (see Blocher 1997: 18). First, original sin is universal sinfulness, consisting of attitudes, tendencies, and an inclination to sin, to evil, which the Belgic Confession states is extended to all mankind' (Article 15), and 'which is a corruption of the whole nature'. Thus, 'he made himself liable to corporal and spiritual death. And being thus become wicked, perverse, and corrupt in all his ways, he hath lost all his excellent gifts which he had received from God'.

Second, original sin is natural sinfulness (peccatum naturale): it belongs to human nature in a real sense and is present from birth; we are born with a fallen human nature. In the Heidelberg Catechism the corruption of 'our nature' is traced to 'the fall and disobedience of our first parents, Adam and 
Eve' and hence 'we are all conceived and born in sin' (Q. 7). So, too, in the Second Helvetic Confession, 'we take sin to be the natural corruption of man, derived or spread from our first parents unto us all, through which we, being drowned in evil concupiscence, and clean turned away from God, but prone to all evil, full of all wickedness, distrust, contempt, and hatred of God' (VIII.2). In sum, the doctrine of original sin is about original corruption and original guilt. We find both aspects in the Westminster Shorter Catechism Q. 18: "Wherein consists the sinfulness of that estate where into man fell?" To which the following response is made: "The sinfulness of that estate where into man fell, consists in the guilt of Adam's first sin [first aspect], the want of original righteousness, and the corruption of his whole nature, which is commonly called Original Sin [second aspect]; together with all actual transgressions which proceed from it"'.

Third, original sin is inherited sinfulness: this fallen human nature is inherited from Adam, which results in human beings that are born in a state or condition of corruption of the whole nature of man, and a hereditary moral weakness and alienation or estrangement from God, now having lost the grace of original holiness and righteousness. The Belgic Confession states the same: 'original $\sin$ is ... a hereditary disease, wherewith infants themselves are infected even in their mother's womb, and produceth in man all sorts of sin, being in him as a root thereof, and therefore is so vile and abominable in the sight of God that it is sufficient to condemn all mankind' (Article 15). Man's corrupt nature is closely connected with God's judgment and wrath and this rests on the presupposition of original sin.

And fourth, original sin is Adamic sinfulness: it stems from Adam, who committed the first sin, the primal sin, and whose disobedience toward God gave original sin a historical beginning, and which has left its consequence in every descendant of Adam, so that the sinful situation of humanity is connected with the fault of Adam, the first man and progenitor of the human race. Adam is the head of the humanity. In this light, we can understand why we are children of Adam. As the Westminster Shorter Catechism puts it, 'The covenant being made with Adam, not only for himself, but for his posterity; all mankind, descending from him by ordinary generation, sinned in him, and fell with him, in his first transgression' (Q. 16). He is 'the root of all mankind', states the Westminster Confession of Faith, and hence 'the guilt of [his] sin', and not just the punishment, 'was imputed; and the same death in sin, and corrupted nature, conveyed to all their posterity descending from [him] by ordinary generation' (VI.3). In this connection, the Westminster Larger Catechism importantly notes that the universality of $\sin$, the guilt of $\sin$, is conveyed by from our first parents unto their posterity by natural generation', not imitation, 'so as all that proceed from them in that way are conceived and born in sin' (Q. 26). 
Pace Pelagianism, it is telling that following Adam's example is not the way that sin is transmitted to us since St. Paul states in Romans 5:14 that death held dominion over all men who lived between Adam and Moses, 'even though their sin, unlike that of Adam, was not a matter of breaking the law'. Similarly, Canon XI of the Formula Consensus Helvetica states, 'man, because of sin, is by nature, and hence from his birth, before committing any actual sin, exposed to God's wrath and curse; first, on account of the transgression and disobedience which he committed in the loins of Adam; and secondly, on account of the consequent hereditary corruption implanted to his very conception, whereby his whole nature is depraved and spiritually dead; so that original sin may rightly be regarded as twofold, imputed sin and inherent hereditary sin' (Dennison 2014: 523).

So, too, the Belgic Confession emphasizes the hereditary character of sin, 'Wherefore we reject the error of the Pelagians, who assert that sin proceeds only from imitation' (Article 15). The distinction here is a gloss on Romans 5:12: 'Therefore, as sin came into the world through one man and death through sin, and so death spread to all men because all men sinned'. In other words, sin did not spread to all men because all men sinned by example but rather because all of us participate in the sin of Adam. The universal sinfulness of man refers back to Adam's sin in whom all men participate rather than the individual bringing judgment upon himself because he imitates Adam's sin. Again, the Formula Consensus Helvetica, Canon XII, states: '[W]e cannot, without harm to the Divine truth, agree with those who deny that Adam represented his posterity by God's intention, and that his sin is imputed, therefore, immediately to his posterity'.

The Reformed confessions hold that the primal sin of Adam and Eve, our first parents, is the historical foundation of human sinfulness. The question raised here is about the justice of God's imputation of Adam's sin to all men. While preserving divine justice, the confessions link human sinfulness and the primal sin by virtue of human solidarity with Adam. How, then, should solidarity be understood?

\section{Realism vs Federalism}

Regarding the stress on solidarity, two accounts have been given of the nature of this human solidarity, namely, realism and federalism, in order to deal with the difficult problem of 'how one person could be liable for the guilt of another' (Crisp 2006: 58; see also, Berkouwer 1960: 207-247; 1971: 436-465). Berkouwer is persuaded that 'federalism, as well as realism, is lacking in the Reformed confessions' (1960: 304; 1971: 524). The appeal to human solidarity does not explain the imputation of the sin of Adam to his posterity. That is why both accounts are attempting to deal with man's own guilt while preserving God's justice. Realism is the view that all men are 'somehow 
metaphysically one entity with Adam such that Adam's sin just is the sin of the whole of humanity' (Crisp 2006: 55; see also, Berkouwer 1960: 229; 1971: 446). This view, explains Bavinck, operates with the presupposition of 'an organic unity, one race, [and] one family'. Furthermore, Adam has a distinctively singular place as the 'seminal beginning of the whole human race, our common natural head'. Bavinck adds underscoring the claim of Augustinian realism such that we were all in that one man who fell into sin: "In a sense it can be said that "we all were that one human", that what he did was done by us all in him. The choice he made and the action he undertook were those of all his descendants. So it is also with Adam: virtually, potentially, and seminally, we may have been comprehended in him' (Bavinck 1987: 102; 2004: 80). This solidarity with Adam is both social and ontological. 'We were all in that one, when we were all that one.' This sentence is a portion of Augustine's affirmation in the City of God XIII.14 of realism: 'For we all were in that one man, since we all were that one man, who fell into sin by the woman who was made from him before the sin'. There is no imputation here of a peccatum alienum because 'we were there in Eden, and we committed the transgression there and then' (Blocher 1997: 114) Similarly, Henri Blocher explains, 'The realist [unindividualized whole of humanity version of Augustinian realism] explanation is fraught with a number of difficulties. "Realizing" the idea of nature so strongly that it becomes numerically one, as a substance, with a history of its own, demands a rather extreme form of Platonism' (1997: 115).

Now, if by ontological presence or identity is meant seminally present, and hence physically present, at the moment of primal sin, this presupposes a version of Platonic and Plotinian ideas of the pre-existence of the soul, meaning thereby that 'in some sense, our souls partake of the common life of the human race, in Adam, before they enliven our own bodies' (Couenhoven 2005: 368). In other words, St. Paul's words in which the sin of 'one man' is seem as the sin of 'all' presumes the all pre-exists in 'the ur-reality of the one man' (Berkouwer 1960: 298; 1971: 517). From the viewpoint of Christian anthropology, this construal of metaphysical unity in which humanity as a whole is present and unindividualized in Adam is plainly false, indeed, theologically heterodox (Crisp 2006: 61). But metaphysical unity may be construed differently, namely, human nature is one metaphysical entity that is shared by Adam-plus-progeny. Crisp explains:

One way that some Augustinian realists have understood the union of Adam and his progeny maintains that Adam and his posterity are separate individuals that participate in a common fallen human nature. If this human nature is corrupted by Adam's first sin, then it is corrupted in the subsequent individualization of that nature in an infralapsarian state.

Consequently, all humanity actually or really sinned 'in' Adam, since all humanity actually or really share in a common human nature. Let us call this the 
common human nature version of Augustinian realism, or 'common nature version' for short (Crisp 2006: 61).

We will see below that the common human nature version of Augustinian realism is shared by the Roman Catholic tradition. For now, a critical question must be raised. Although an important version of Augustinian realism because it highlights the unity of the human race, it remains to ask whether it satisfactorily accounts for the imputation of guilt 'on individual man himself and his own being guilty, personally, and by means of his own activity' (Berkouwer 1960: 229; 1971: 446). That is, adds Berkouwer, 'One can only speak of imputation in regard to what a man himself has done; and man's own guilt can only be written on his own account' (Berkouwer 1960: 233; 1971: 451; Blocher 1997: 115). As Crisp explains admirably well, 'This account of imputation may, as we shall see, point in the direction of a solution to the injustice problem, but it does not, as it stands, provide a satisfactory account of how it is that God may justly impute the sin of Adam to his posterity. For it is not clear thus far, on this view, how it is that God is able to treat Adam and his posterity, as generically and numerically one metaphysical unit for the purposes of the imputation of sin' (emphasis added) (Crisp 2006: 61). According to Bavinck, then, realism, however satisfactory in other respects, loses sight of the 'independence of the human personality'. A human is a member of the race as a whole, certainly, but in the whole he or she occupies a unique place of his or her own. Individuals are more than ripples in the ocean, more than passing manifestations of human nature in general' (Bavinck 1987: 81; 2004: 102; see also Berkouwer 1960: 230; 1971: 447).

Almost one hundred years later the same objection is raise by French Evangelical Reformed theologian, Henri Blocher: 'What the "realist" proposal tends to sweep under the carpet is the primary datum of individual responsibility, of individuality as such. Even if the language of extreme realism were adopted, the difficult step would still be there: how do we move from seminal participation, or ideal nature, to the distinct existence of individuals? It is they who stand condemned as guilty' (1997: 115). Thus, we need an understanding of imputation that does not block from sight the individual who is held responsible for what he has actually done.

Of course, neither Berkouwer nor Bavinck object to realism. Berkouwer, for one, states, 'the concept of race or humanity is imported to aid us in resolving the internal problematic of a real co- sinning' (Berkouwer 1960: 229; 1971: 446). Therefore, we need to preserve in our reflections on the doctrine of original sin 'the central idea that the whole race is in some strong sense metaphysically united with Adam in virtue of sharing the same kind of essence as Adam' (Crisp 2006: 64). Crisp elaborates: 
But it does not do so via the notion that the race is present with Adam as some undifferentiated whole, rather than as a group of individual human beings. Instead, the common nature view seems to be that Adam's sin affects human nature, and that this vitiated human nature is what is transferred to each individual human being thereafter. Once this generic human nature is corrupted in Adam, every other individualization of that nature in each subsequent individual member of the human race will carry the same imprint of corruption. Put another way, on the common nature version of realism sin is transmitted via a generic human nature shared with Adam. In the second version, the unindividualized version, there is no transmission of sin involved because original sin affects all of humanity before it is differentiated into different individuals (Crisp 2006: 65).

Crisp sketches a moderate version of Augustinian realism, a version that does not presuppose an unindividualized whole of humanity but does hold on to the common nature version. On this version of realism, explains Crisp, 'Adam's sin affects human nature, and ... this vitiated human nature is what is transferred to each individual human being thereafter' (Crisp 2006: 65). If the problem with unindividualized whole of humanity version of Augustinian realism is that sin is transmitted before human nature is differentiated into different individuals, then the common nature version doesn't have that problem because the fallen human nature is individualized in each subsequent individual member of the human race. On this view, God's imputation of Adam's sin to me is such that his sin is my sin rests on the presupposition that post-Adamic individuals are somehow really united together with Adam. There is an actual co-sinning in Adam because "the "all" are actually in the “one" (Berkouwer 1960: 292-293; 1971: 511 ).

Federalism is another influential view attempting to account for the nature of solidarity such that it is able to show that God is just in imputing Adam's sin to me. What, then, is the unique significance of Adam's sin for the entire human race? Federalism holds that the first human being, Adam, is the representative head of humanity, acting not only on behalf of the whole human race but also in its place. The nineteenth-century Scottish theologian, William Cunningham, explains this view:

In virtue of the federal headship or representative identity, established by God between Adam and all descending from him by ordinary generation, his first sin is imputed to them, or put down to their account; and they are regarded and treated by God as if they had all committed it in their own person, to the effect of their being subjected to its legal and penal consequences-so that, in this sense, they may be truly said to have sinned in him and fallen with him in his first transgression (1967: 374). 
Can federalism bear the theological weight of justifying the imputation of Adam's sin in a way that is just when in question is whether there is an active and a personal sinning?

Bavinck claims that federalism includes realism but goes beyond it because the solidarity as such of the human race does not justify God's imputation of Adam's sin to his posterity (1987: 83; 2004: 104). There must be a real guilt and to a man's sin as peccatum proprium. Still, federalism speaks of Adam representing the entire human race and in that light declaring, judging, and regarding man as guilty. Here the relation between the 'all' and the 'one' is thought of in a representative manner. But unlike realism, notes Berkouwer, "The "all" are accounted with the "one" on the basis of the ordinatio Dei or divine decree' (Berkouwer 1960: 292-293; 1971: 511). He explains the difference between realism and federalism as regards a 'real imputation of man's guilt'.

Realism says that imputation is only thinkable when all posterity are 'actually and really co-sinners', while federalism clings to the phrase 'in a certain sense' and contends that God regards and treats, and therefore declares all men as guilty in Adam. Here' however, it is clear that our problem [of a justifying a real imputation of man's guilt] is no less real. Both parties agree that there is an actual 'imputation' of guilt and not a merely external act; yet they cannot come to terms at the deeper level as long as the religious charge of realism has any ring of validity. The charge is that the federalist 'declaration of guilt' is nothing but an act of God's caprice. According to the realists, it cannot be more than that as long as the federalists refuse to accept the premise that Adam's sin is the sin of all men in the fullest and most realistic sense of those words. Therefore, the question of the meaning of imputatio returns as the question of God's ordinatio [in Adam]. This, then, is the concept [God's ordinance] which the federalists have used as the basis for the imputation of Adam's guilt to all (Berkouwer 1960: 238-239; 1971: 457).

Berkouwer hits right on the mark the core problem with federalism, namely, an arbitrary God, which means that federalism has a problem with injustice. He adds, 'Realism has done us the service of sharpening our insights concerning the meaning of imputatio. It has tried to answer the question of whether God imputes to men an "alien guilt". Is the concept of imputatio at odds with the very nature of his justice?' (Berkouwer 1960: 242; 1971: 460). Although I cannot fully argue the point here, I agree with Berkouwer that in federalism with its idea of representation and the corresponding notion of imputatio by virtue of God's ordinance in Adam 'leaves the impression that the unguilty are merely "declared" to be guilty' (Berkouwer 1960,: 304; 1971: 524). This raises again the question of God's capriciousness because imputatio is related 'to something which, as a matter of fact, is not real' (Berkouwer 1960: 298; 1971: 517). However, without personal or actual guilt it is wrong to impute the guilt of Adam's sin to indict posterity. Some theologians in the 
Reformed tradition sought to deal with the problem of the injustice of suffering for someone else's sin by distinguishing between inherited guilt and hereditary depravity or corruption. This distinction raises the question regarding the nature or mode of imputation. Is it immediate or mediate imputation? The former means that Adam's guilt is directly or immediately imputed to his posterity in their unindividuated existence; it thus logically precedes and is the cause of hereditary depravity. Mediate imputation reverses their causal relationship for the guilt of Adam's sin follows hereditary depravity and is its effect. Crisp is correct, however, because mediate imputation denies 'the obvious consequence of a full-blooded doctrine of original sin with respect to original guilt. This is that if one is truly guilty of Adam's sin one must participate in that sin. Far better, it seems to me, to simply concede the injustice question and embrace the fact that Adam's sin and guilt are (somehow) my sin and guilt for which I am culpable, as per realism' (Crisp 2006: 70). Hence, this leaves the charge standing that federalism does not resolve the question of injustice.

\title{
Trent on Original Sin
}

Trent's decree on Original Sin reiterates the four elements to the doctrine of original sin: universal sinfulness, natural sinfulness, inherited sinfulness, and Adamic sinfulness.

\begin{abstract}
If anyone does not profess that Adam, the first man, by transgressing God's commandment in paradise, at once lost the holiness and justice in which he had been constituted; and that, through the offense of this sin, he drew upon himself the wrath and indignation of God and consequently death with which God had threatened him and, together with death, captivity in the power of him who henceforth 'has the power of death' [Heb 2:14], that is, the devil, and that 'the whole Adam, body and soul, was changed for the worse through the offense of his sin' [Council of Orange, Denzinger Canon 1, 371], let him be anathema (Denzinger §1511).
\end{abstract}

Adam's primal sin is the basis of original sin; it differs from and is prior to original sin. Adam disobeyed a divine command and hence lost holiness and justice, incurring God's wrath and consequently the punishment of death, and, furthermore, he was as a whole, both body and soul, changed for the worse. Aquinas held that original sin is the absence of original justice, "the disordered disposition rising from the dissolution of that harmony in which original justice consisted' (Aquinas STh I-II, q. 82, aa. 1-3). The Catechism of the Catholic Church $\$ 400$ explains: 'The harmony in which they [Adam and Eve] had found themselves, thanks to original justice, is now destroyed: the control of the soul's spiritual faculties over the body is shattered; the union of man and woman becomes subject to tensions, their relations henceforth marked by lust and domination. [Gen 3:7-16] Harmony with creation is 
broken: visible creation has become alien and hostile to man [Genesis 3: 17, 19]. Because of man, creation is now subject "to its bondage to decay" [Romans 8:21]. Finally, the consequence explicitly foretold for this disobedience will come true: man will 'return to the ground' [Genesis 3:19] for out of it he was taken. Death makes its entrance into human history.

Significantly, Trent asserts that Adam's sin meant not only the loss of holiness and justice for him but also for his posterity such that the sin of Adam is the sin of all men.

'If anyone asserts that Adam's sin harmed only him and not his posterity' and that the holiness and justice received from God that he lost was lost only for him and not for us also; or that, stained by the sin of disobedience, he transmitted to all mankind 'only death' and the sufferings 'of the body but not sin as well, which is the death of the soul', let him be anathema. For he contradicts the words of the Apostle: 'Sin came into the world through one man and death through sin, and so death spread to all men as all sinned in him' [Romans 5:12, Vulgate. Canon 2, 372] (Denzinger §1512).

Denzinger uses the old Vulgate translation of Romans 5:12. Here is the Latin for Romans 5:12 in the Nova Vulgata approved by John Paul II in 1979. 'Propterea, sicut per unum hominem peccatum in hunc mundum intravit, et per peccatum mors, et ita in omnes homines mors pertransiit, eo quod omnes peccaverunt.' Trent asserts here that all men are implicated in the sin of Adam. In what sense? The Catechism of the Catholic Church $\$ 404$ poses this question: 'How did the sin of Adam become the sin of all his descendants?' Although Trent's decree on Original Sin does not answer this question, whether it must be viewed, for example, as 'realistic' or as 'federal', the Catechism takes a position that shows a clear relation to realism-indeed, the common human nature version of Augustinian realism (Berkouwer 1960: 245; 1971: 464) rather than its unindividualized whole of humanity version in which men acted in Adam. The Catechism also does not interpret Trent's decree as if Adam represented all men, which is the federalist view. However, Ludwig Ott suggests a connection between the 'realistic' and 'federal' views. 'Adam was the representative of the whole human race. On his voluntary decision depended the preservation or the loss of the supernatural endowment, which was a gift, not to him personally but, to human nature as such. His transgression was, therefore, the transgression of the whole human race' (Ott 2018: §22.2). Here we find the common human nature version: "The whole human race is in Adam "as one body of one man"' [Aquinas, Demalo 4, 1]. Surprisingly, the Catechism does not cite from Aquinas' Summa Theologiae I-II, q. 81, art. 1: '[A]ll men born of Adam may be considered as one man, inasmuch as they have one common nature, which they received from their first parents ... Indeed Poryphyry says ... that by sharing the same species, many men are 
one man. Accordingly, the multitude of men born of Adam, are as so many members of one body'. This passage is a fitting segue to the rest of the Catechism's explanation ( $\$ 404-405)$.

By this 'unity of the human race' all men are implicated in Adam's sin transmission of original sin is a mystery that we cannot fully understand. But we do know by Revelation that Adam had received original holiness and justice not for himself alone, but for all human nature. By yielding to the tempter, Adam and Eve committed a personal sin, but this sin affected the human nature that they would then transmit in a fallen state ...

Although it is proper to each individual [emphasis added], original sin does not have the character of a personal fault in any of Adam's descendants.

The Catechism is clear here that the sinful personal act of Adam, his actual $\sin$, is not inherited. What does this mean? Adam's sin is not a sin that we personally commit. Thus, the Catechism states, 'And that is why original sin is called "sin" only in an analogical sense: it is a sin "contracted" and not "committed" - a state and not an act'. Yes, but I have a sense that this distinction has not been properly understood. If original sin is called sin only in an analogical sense that means we must distinguish that sense from univocal and equivocal senses (Aquinas STh I, q. 13, a. 5). Univocal means that the concept of sin would have the same meaning in each instance of application; equivocal would mean that it has a completely different meaning. Thus, regarding the univocal sense the Catechism is right that original sin does not have 'the character of a personal fault in any of Adam's descendants'. However, it cannot be an equivocal sense either because then original sin would not be proper to each individual. 'Sin' in original sin is analogous in its sense meaning thereby that it is similar in each instance of application: Adam and his descendants. So, in some analogous sense we all participate in the sin of Adam and hence in his guilt. I shall show below that this idea of participating in the sin of Adam is supported by Trent's teaching on baptism. For now, let me say that this, too, is the view of Aquinas following from what I cited from him above, namely, 'all men born of Adam may be considered as one man'.

Accordingly the multitude of men born of Adam, are as so many members of one body. Now the action of one member of the body, of the hand for instance, is voluntary not by the will of that hand, but by the will of the soul, the first mover of the members. Wherefore a murder which the hand commits would not be imputed as a sin to the hand, considered by itself as apart from the body, but is imputed to it as something belonging to man and moved by man's first moving principle. In this way, then, the disorder which is in this man born of Adam, is voluntary, not by his will, but by the will of his first parent, who, by the movement of generation, moves all who originate from him, even as the soul's will moves all the members to their actions. Hence the sin which is thus transmitted by the first 
parent to his descendants is called 'original', just as the sin which flows from the soul into the bodily members is called 'actual'. And just as the actual sin that is committed by a member of the body, is not the sin of that member, except inasmuch as that member is a part of the man, for which reason it is called a 'human sin'; so original sin is not the sin of this person, except inasmuch as this person receives his nature from his first parent, for which reason it is called the sin of nature (Aquinas STh I-II, q. 81, a. 1).

The sinful state of human nature is a consequence of Adam's sinful personal act, and that sinful act is transmitted to posterity by virtue of inheriting his nature from Adam. Thus, the sinful state is transmitted to Adam's posterity. 'It is a sin which will be transmitted by propagation to all mankind, that is, by the transmission of a human nature deprived of original holiness and justice.' Here the Catechism echoes the third decree of Trent that Adam's sin 'is one in origin and is transmitted by propagation, not by imitation, and which is in all men, [and] proper to each'. All of us participate in the sin of Adam, not merely by virtue of the consequence of sin that is externally imputed to us, but sin itself and its guilt. How is, then, the sin of Adam in all men, and in what analogical sense is it proper to each man's sinning?

Well, the sin of Adam is in all men by virtue having inherited a fallen human nature from Adam and Eve. The crucial question is-as Ott puts itwhether proper to each man's sinning is a true and proper sin, that is, a sinful fault (culpa). St. Paul speaks of a real sin; Romans 5:12: "All have sinned”" (Ott 2018: §22.1). Trent's decree on original sin is not clear as it could be regarding the nature of the reality of original sin. Still, we can find textual evidence about the sacrament of baptism to support Ott's interpretation, namely, that this sacrament frees us from sin, guilt, unrighteousness, and condemnation. For instance, in Denzinger $\$ 1514$ : 'If anyone denies that infants, newly born from their mothers' wombs, are to be baptized, even though they be born from baptized parents, "or says that they are indeed baptized for the remission of sins, yet they do not contract from Adam any trace of original sin that must be expiated by the bath of regeneration" that leads to eternal life, so that in their case the formula of baptism "for the forgiveness of sins" would no longer be true but would be false, let him be anathema. For, what the Apostle says, "Sin came into the world through one man and death through one sin, and so death spread to all me as all sinned in him” [Romans 5:12]'. Again, consider Denzinger $\$ 1515$, where Trent states, 'If anyone denies that the guilt of original sin is remitted by the grace of our Lord Jesus Christ given in baptism or asserts that all that is sin in the true and proper sense is not taken away but only brushed over or not imputed, let him be anathema'. Later in Denzinger $\$ 1523$ of Trent's Decree on Justification, Chapter 3, states, 'For, as truly as men would not be born unrighteous if they were born children of Adam's seed, since it is because of their descent 
from him that in their conception they contract unrighteousness as their own, likewise they would never be justified if they were not reborn in Christ [canons 2 and 10], for it is this rebirth that bestows on them, through the merit of his Passion, the grace by which they becomes just'. Pace Scott Hahn, then, 'Liability for his [Adam's] actions cannot be imputed to his descendants, but the effects of his transgression can still be felt by them' (Hahn 2017: 87). For all of us participate in the sin of Adam, not merely by virtue of the consequence of sin that is externally imputed to us, but sin itself and its guilt. We all, then, participate in the sin of Adam, and that in an analogical sense-but no less meaningful sense for that-because participation is proper to each man's sinning.

Furthermore, in Denzinger $\$ 1512$, Trent's decree on original sin, it intends to follow here Canon 2 of the Second Council of Orange, which canon also alludes to the Synod of Sens (1141), in which the idea is rejected that from Adam man has contracted punishment for original sin, but not sin and guilt itself-which is the 'death of the soul'. Sin itself was passed on to the whole human race by one man; otherwise, 'he ascribes an injustice to God'. As Germain Grisez explains, '[I]f we share in the punishment for Man's [Adam's] sin, we must also somehow share in the sin itself, since otherwise God would be punishing us unfairly for a sin in no way our own' (Grisez 1983: 336). Pier Franco Beatrice elaborates on this point: 'When ... one speaks of hereditary sin, the idea is that Adam transmitted to his descendants not just the punishment for his sin, but the sin itself. In this manner, men are born not only subject to physical death, pain, and the other limitations inherent in their debased nature, deprived as it is of the image of God. In addition, they come into the world in a condition of actual sin, which renders them worthy of eternal damnation' (Beatrice 2013: 6). However, how can the sin and hence guilt of Adam be our own? We have met this question earlier in our discussion of the Reformed confessions, and hence it is a question that both Catholics and Protestants have asked (Berkouwer 1960: 243-247; 1971, 461-465). Aquinas suggests a possible answer to this question:

The son is said not to bear the iniquity of his father, because he is not punished for his father's sin, unless he share in his guilt. It is thus in the case before us: because guilt is transmitted by the way of origin from father to son, even as actual sin is transmitted through being imitated (Aquinas STh I-II, q. 81, a. 1, r. 1).

A man is not blamed for that which he has from his origin, if we consider the man born, in himself. But it we consider him as referred to a principle, then he may be reproached for it: thus a man may from his birth be under a family disgrace, on account of a crime committed by one of his forbears (Aquinas STh I-II, q. 81 , a. 1, r. 5 ).

According to Augustine in his letter to Avitus [Ep. ad Auxilium ccl.], children are never inflicted with spiritual punishment on account of their parents, unless they share in their guilt, either in their origin, or by imitation, because every soul 
is God's immediate property, as stated in Ezekiel 18:4. [Behold, all souls are mine; the soul of the father as well as the soul of the son is mine: the soul who sins shall die.] Sometimes, however, by Divine or human judgment, children receive bodily punishment on their parents' account, inasmuch as the child, as to its body, is part of its father (Aquinas STh I-II, q. 81, a. 2).

Edward Oakes suggests, 'Thomas is groping toward some kind of corporate solution' (Oakes 2015: 136). He does not develop this suggestion, but Berkouwer (1960: 293-298; 1971: 512-518) and Ridderbos (1973: 56-63; 1975: 57-64) have helpfully done so.

Corporative thinking means that we work with the idea of a 'corporate personality' such that it would be the case, says Berkouwer, 'the group participates in what the individual Adam does. One man represents the whole of humanity'. He adds, 'If Adam is guilty, then all men are guilty; if Adam dies, then all men die. What is more, this does not occur in a "latter sinning". For even in the absence of strictly individual sins, all the true "sons of Adam" are sinners. In this sense the entire human race is "there present and take part in his destiny of sin and death" (Berkouwer 1960: 295; 1971: 514). This framing is reminiscent of the unindividualized version of Augustinian realism that we earlier discussed and criticized. However, Berkouwer rejects this version. 'Within his [Paul's] corporative mode of thought it is entirely impermissible to adopt the conclusions of either realism or federalism. This is because realism converts the words of Paul into an anthropological concept in which the corporative aspect can only be cancelled our (speculatively) by an assumed "preexistence" in man's ur-reality' (Berkouwer 1960: 298; 1971: 517). Unlike Aquinas, Berkouwer is reluctant to use the idea of causality between the undeniable connection and solidarity in death and guilt between Adam and his posterity. In other words, he refuses to explain, within limits, this undeniable solidarity in theoretical terms such as either realism or federalism. He insists that Paul has no intention of explaining the universality of sin. 'Paul does not explain the manner in which the sin of "one man" is transferred to "all men" (Berkouwer 1960: 297; 1971: 516). He adds, 'Paul was not concerned about the manner in which the sin of one man is "transferred" to another, or the manner in which the pollution of one generation "becomes" that of another' (Berkouwer 1960: 291; 1971: 510). Berkouwer explains, 'metaphysical, anthropological and "realistic" ideas have always been wrongly deduced from a "corporative" mode of thought. On the surface, of course, there would seem to be a greater affinity between the "corporative" and "representative" ideas; also, this fact would seem to be apparent when we hear of a "representation" as a means of clarifying the relation between the "all" and the "one" (Berkouwer 1960: 304; 1971: 524). But let us recall that federalism with its idea of representation and the corresponding notion of imputatio by virtue of God's ordinance in Adam left us with 'the impression that the unguilty are 
merely "declared" to be guilty' (Berkouwer 1960: 304; 1971: 524). Thus the problem of the actual guilt of man-our own guilt-and the just punishment of God. Ultimately, Berkouwer gives a negative answer to the question as to whether there can a "explainable continuity" between Adam's sin and his posterity. 'In this very question we are tempted to overstep the boundaries of our faith and to put to nought the confession of our guilt' (Berkouwer 1960: 306; 1971: 526). The rejection of an explainable continuity in terms theoretical frameworks such as realism or federalism 'does not mean a watering down of the gravity of guilt but an accentuation of guilt in the form of a confession' (Berkouwer 1960: 311; 1971: 531). Concretely, this means that Berkouwer approaches the question of the 'inescapability of universal guilt' in light 'of the cross and God's judgment upon man's sin. In that perspective man's sin is no longer seen as peccatum alienum. Rather, it is both known and confessed as peccatum proprium.

That is to say, it is both known and confessed as 'man's own' (Berkouwer 1960: 312; 1971: 532). Interestingly, Berkouwer's approach bears a certain affinity to the teaching of the Catechism of the Catholic Church: the 'transmission of original sin is a mystery that we cannot fully understand' (\$404). Hence, rather than search for “"explainable continuity"' between Adam's sin and his posterity, the Catechism 'contrasts the universality of sin and death with the universality of salvation in Christ' (\$402). 'Only the light of divine Revelation clarifies the reality of sin and particularly of the sin committed at mankind's origins. We must know Christ as the source of grace in order to know Adam as the source of sin' ( $\S 387-388)$. In sum:

The doctrine of original sin is, so to speak, the 'reverse side' of the Good News that Jesus is the Savior of all men, that all men need salvation, and that salvation is offered to all through Christ. The Church, which has the mind of Christ, knows very well that we cannot tamper with the revelation of original sin without undermining the mystery of Christ (\$389).

I shall return to this Christocentric perspective in the final section of this article.

Returning now to Trent's point (Denziger §1512) that the sin of Adam, and not just his punishment, has been transmitted to his posterity. Thus, we share in the sin itself, and this point is justified by reference to Romans 5:12 on pain of contradiction. 'Therefore, as sin came into the world through one man and death through sin, and so death spread to all men, inasmuch as ["because" or "with the result that"] all men sinned.' Denzinger explicitly uses a variation of the received Latin translation (Vulgate) in quo ('in whom' or 'in which') for Paul's original eph'o (now translated as 'because' or 'inasmuch as'). Berkouwer asks: 'Is there an essential difference implied when we change the translation from in whom to because [or 'inasmuch as']? Or is there no 
difference at all?' (Berkouwer 1960: 274; 1971: 492). Berkouwer warns against interpreting because to mean that there is no reference to a sinning in Adam but rather to the actual sins of men.

The idea here is that the concept of because suggests an assertion that sin has come into our world by man, that through man's sin comes death, and that death has now passed on to all men, since all men are sinners, even though their sinning comes later (Berkouwer 1960: 275; 1971: 493).

Still, although this Pelagian exegesis is untenable, the motive is important, namely, taking account of our own personal guilt. In light of this motive, I think we can argue that the personal sins of the many that come later are a consequence of the sin of the one. This argument is important because 'we cannot escape our guilt', as Berkouwer correctly notes. He adds, 'for universal guilt is manifest in the modus of our guilt. Furthermore, in this perspective of our guilt it is impossible to disparage the justice of God or to refer to his righteousness as caprice. This point it seems to us, is the most critical issue in any reflection on the guilt of all mankind' (Berkouwer 1960: 302; 1971: 522).

By contrast to this Pelagian interpretation where there is no reference to sinning in Adam, Berkouwer sides with a chorus of voices who maintain that the new translation of Romans 5:12 still has a 'substantial reference to a "sinning in Adam". He explains:

It is especially important, they say, to notice what Paul writes about the era between Adam and Moses. Sin was certainly in the world, according to Paul, in this 'prelaw' period; yet because there was no law man's sin was not 'imputed'. At the same time, death continued to reign supreme in the lives of those who sinned, even though they sinned in a different way from Adam. In this description of the period from Adam to Moses the inference is now drawn that Romans 5:12 cannot possibly entail a latter, personal sinning. Rather, the 'regnancy' of death has everything to do with the sinning of all men in one. Therefore, this text can rightly be paraphrased: 'because all men sinned in Adam'. Thus Bavinck [finds the inclusion of all men in Adam entirely apart from the translation of in whom Paul's purpose was to point to the involvement of all men in the sinning of the one (Berkouwer 1960: 275-276; 1971: 493-494).

In other words, condemnation and death is grounded upon and proceeds from the one sin of the one man Adam. The context of Romans 5:12, namely, verses 15-19, makes that abundantly clear: 'many died through one man's trespass' (vs. 15); 'For the judgment following one trespass brought condemnation' (vs.16); 'because of one man's trespass, death reigned through that one man' (vs. 17); 'as one trespass [or the trespass of one] led to condemnation for all men' (vs. 18); 'by the one man's disobedience the many were made sinners' (vs. 19). As John Murray correctly observes: 'It is quite impossible to 
construe this emphasis upon the one sin of the one man as equivalent to the actual personal sin of countless individuals' (Murray 1959: 11).

Yes, not equivalent, but we can look upon the sins of the many as a consequence of the sin of the one. As I cited Berkouwer above, 'for universal guilt is manifest in the modus of our guilt ... [This] is the most critical issue in any reflection on the guilt of all mankind'. It in the light of this critical issue that we should understand Catholic theologian, Edward Oakes, point about dual causality. He writes: 'That interpretation [the Vulgate] is now universally rejected; because if that had been Paul's meaning, he would have said en hō. But in an important article Joseph Fitzmyer, after a careful examination of the extant secular and religious literature, shows that the phrase could also be translated as 'with the result that' (this is called in the grammar books the 'consecutive sense'). 'Paul in v. 12 would be ascribing death and human sinfulness to two causes, not unrelated: to Adam and to the conduct of all human beings. For no one sins entirely alone and no one sins without adding to the collective burden of mankind' (Oakes 2016: 132; see also, Hahn 2017: 87).

Given the limits of this paper, I have said enough about the justice of God's judgment on all men. However, that still leaves unanswered the question of preterition. That question will need to be reconsidered briefly, and in conclusion, in light of the doctrine of divine election, in particular, preterition, with its impact upon evangelization-kerygmatic universality. Returning to my claim at the outset of this article that the seriousness of preaching the gospel was at odds with, not to say endangered by, another aspect of the Canons of Dort, namely, its presupposition of unconditional negative reprobation or preterition, consider the words of Peter Martyr Vermigli (1499-1562):

[A]ll men are in misery through their own [fallen] nature. God delivers some out of this misery; those he is said to love. Others he passes over, and those he is said to hate, since he has not had mercy on them, so that by their just condemnation he might declare his anger against sins and also his justice. The damnation of these men is said to be just because it is inflicted upon them for their sins. Yet we should not infer from this that foreseen sins are the cause of a man's reprobation. Sins do not cause God to intend not to have mercy; however, they are the cause of damnation, which follows in the last judgment, that was prepared from the beginning (Vermigli 2018: 25).

Again, what is the basis for this unequal treatment of people? People are condemned because of their sin, but not passed over because of it; so, then, how are they responsible for their rejection of God?

How can the gospel be proclaimed to all men? How can the reprobatethose that God has passed over-be held accountable for their failure to respond to the gospel? Clearly, the ones passed over will never receive the grace to respond to the Gospel. Surely, this gives men reason to be pessimistic, 
rendering the doctrine of divine election as something that is fallen under a shadow.

The issue here is not only of fairness of God's character, in which the question is raised of the moral responsibility of non-elect given God's preterition; it is also, indeed, chiefly, of God's love. This, too, is the objection of Scottish Presbyterian theologian, James Orr (1844-1913): 'We are sure that if God is sovereign, yet not sovereignty but love must be enthroned as the central principle of His character' (Orr 1901: 394). Preterition leads us to the failure to understand that 'God did not send the Son to condemn the world (John 3:17) but that the world should be saved through Him. In sum, the cross takes our sins away because it is the act of God's gracious judgment on Christ for our benefit: 'For our sake he made him to be sin who knew no sin, so that in him we might become the righteousness of God' (2 Corinthians 5:21). The basis is God's love: In this is love, not that we loved God but that he loved us and sent his Son as an atoning sacrifice for our sins' (1 John 4:10). 'For God so loved the world that he gave his own and only Son, that whoever believes in him shall not perish but have eternal life' (John 3:16). 'But God demonstrates his own love for us in this: While we were still sinners, Christ died for us' (Romans 5:8). 'But because of his great love for us, God, who is rich in mercy, made us alive with Christ even when we were dead in transgressions-it is by grace you have been saved' (Ephesians 2:4-5). This saving act arise at once from the will of the Son and of the Father: 'By his obedience unto death, Jesus accomplished the substitution of the suffering Servant, who "makes himself an offering for sin", when "he bore the sin of many", and who "shall make many to be accounted righteous", for "he shall bear their iniquities". Jesus atoned for our faults and made satisfaction for our sins to the Father' (Catechism §615). St. Paul writes, 'Since we have now been justified by his blood, how much more shall we be saved from God's wrath through him. For if, when we were God's enemies, we were reconciled to him through the death of his Son, how much more, having been reconciled, shall we be saved through his life' (Romans 5:9-10).

\section{Divine Election, Preterition, and Evangelization}

Grisez gives an important insight when he suggests that the doctrine of original sin has been 'distorted by considering it outside the context of God's persistent love' (Grisez 1983: 349). Indeed, it has been distorted by considering it outside the context of God's Yes to man in Jesus Christ: 'But as God is faithful, our word to you was not Yes and No. For the Son of God, Jesus Christ, who was preached among you by us... was not Yes and No, but in Him was Yes. For all the promises of God in Him are Yes, and in Him Amen, to the glory of God through us' (2 Corinthians 1: 18-20). This point may be 
developed by considering that the exegetical starting point of Romans 5:1517 is Christ.

But the free gift is not like the trespass. For if many died through one man's trespass, much more have the grace of God and the free gift by the grace of that one man Jesus Christ abounded for many. And the free gift is not like the result of that one man's sin. For the judgment following one trespass brought condemnation, but the free gift following many trespasses brought justification. For if, because of one man's trespass, death reigned through that one man, much more will those who receive the abundance of grace and the free gift of righteousness reign in life through the one man Jesus Christ.

In other words, in the correspondence between Adam and Christ, the former 'must stand in the light of Jesus Christ. Thus, while Adam is seen as the darkness, Christ is the Light which now has come' (Berkouwer 1960: 291; 1971: 510 ). In the words of the Catechism $\$ 385$, 'The revelation of divine love in Christ manifested at the same time the extent of evil and the superabundance of grace [Romans 5:20]. We must therefore approach the question of the origin of evil by fixing the eyes of our faith on him who alone is its conqueror'. This means that God's superabundant grace in Christ is the real message of this chapter. 'Where sin increased, grace abounded all the more, so that, as sin reigned in death, grace also might reign through righteousness leading to eternal life through Jesus Christ our Lord' (Romans 5: 20b-21). Berkouwer elaborates:

It is apparent that Paul refers to this theme [of superabundant grace] in an antithetical analogy. Thus on the one hand we find a framework or parallel that is rooted in the words 'through one man'; on the other hand, there is also a diametrically-opposed antithesis within that framework. The accent on the 'one' or 'many' (or 'all') is repeated in this chapter with remarkable persistency; at the same time we see a decisive antithesis in which two 'men' are set against each other in their importance for the 'all'. Therefore we find those peculiar problems which we have already noted above in our discussion of the realist and federalist hypotheses. We do not get the impression, in Romans 5, that this problematic is a special concern of Paul. Nonetheless it all too often is for us. Certainly Paul did not stop thinking at this point; and yet, his outlook on the superabundance of grace was so central and intense (even when he thought of guilt and death) that nothing could separate him from the love of Jesus Christ. In Romans 5:12ff we hear the continuation of this paean which begins in verses $1-11$. The paean is not interrupted by a tedious or a speculative argument (Berkouwer 1960: 291-292; 1971: 510-511).

How does the superabundance of grace in Christ bear upon the issue of divine election, preterition, and the implications of the latter for evangelization? 
Consider the important passage from the Canons of Dort where the equal symmetry of election and reprobation is categorically rejected.

That the same doctrine of [predestination] teaches that God, by a mere arbitrary act of his will, without the least respect or view to any sin, has predestinated the greatest part of the world to eternal damnation, and had created them for this very purpose; that in the same manner in which election is the fountain [source] and cause of faith and good works, reprobation is the cause of unbelief and impiety [ungodliness]; and many other things of the same kind which the Reformed churches not only do not acknowledge, but even detest with their whole soul (Dennison 2014: 152).

One can surely imagine that the Synod when writing this passage in the Epilogue of the Canons had in mind Canon 17 of the Decree on Justification of the Council of Trent (1547). Trent rejects what is called predestinarianism: 'If anyone says that the grace of justification is given only to those who are predestined to life and that all the others who are called are called indeed but do not receive grace, as they are predestined to evil by the divine power, let him be anathema' (Denzinger $\S 1567$ ). Not to be outdone in hurling anathemas, however, the Synod of Dort 'warns calumniators themselves to consider the terrible judgment of God which awaits them, for bearing false witness against the confessions of so many Churches; for distressing the consciences of the weak; and for laboring to render suspect the society of the truly faithful' ( $C D$, Epilogue). Bavinck added emphatically and incredulously, after citing this very Canon from Trent, 'as if anyone really taught what is contained in this canon!' (1897: 315; 2004: 353). He explains, rejecting an 'equal symmetry' between election and reprobation in their mode of operation: 'The fall, sin, and eternal punishment are included in the divine decrees and in a sense willed by God, but then always in a certain sense and not in the same manner as grace and blessedness' (Bavinck 1897: 351; 2004: 389). Again, Bavinck states: 'Though, on the one hand, there is every reason to consider reprobation as a part of predestination, it is not in the same sense and manner a component of God's decree as election, as the defenders of a double predestination have also at all times acknowledged' (1897: 358; 2004: 395, emphasis added) At all times? Bavinck overstates his point here in rightly rejecting an equal symmetry view of double predestination. Indeed, he emphasizes: 'It is incorrect to represent the wretched state of the lost as the goal of predestination' (Bavinck 1897: 351; 2004: 389). But that there have been supporters of equal symmetry of election and reprobation is beyond doubt. Earlier I quoted the Council of Trent, Canon XVII, on this very point, but the Church made the same point much earlier at the Synod of Orange: 'We not only do not believe that any are foreordained to evil by the power of God, but even state with utter abhorrence that if there are those who want to believe so evil a thing, 
they are anathema' (Denzinger §396-397). This point is reiterated in the $C C C$ $\S 1037$ where the Church teaches, 'God predestines no one to go to hell'. In other words, God did not create some human beings in order to be lost, for the purpose of damnation. This statement must be understood against the background of the Church's rejection of the heresy of predestinarianism, namely, the doctrine of double predestination in the strict sense, as I described it above. For eternal damnation, as the Catechism $§ 1037$ adds, 'a willful turning away from God (a mortal sin) is necessary, and persistence in it until the end' (see Echeverria 2018: 171-216).

And yet, even in the essential asymmetrical view of Dort, one still finds a decree of unconditional negative reprobation, or preterition, meaning thereby that some, namely, the non-elect, are passed over by divine grace. Yes, as I have said before, they are ultimately condemned because of their sin, unbelief, but they are not passed over because of their sin. So, Dort has to deal with the question of equal ultimacy because of the decree of preterition that has a significant place in its scheme of election and reprobation, If so, the problem is, as John Wesley put it, 'You believe he hath absolutely decreed not to save them; and what is this but decreeing to damn them? It is, in effect, neither more nor less; it comes to the same thing' (Wesley 2014: 547).

Berkouwer refers to the Synod's rejection of an 'equal symmetry' between reprobation and election as 'an emphatic denial of what many critics conceive to be an essential part of the orthodox doctrine of election'. He insists that the Synod's 'sharp defense [of an "essential asymmetry"] be honored as an essential motif [of Reformed theology]. For thus, very seriously, do the Canons [of Dort] mean to make clear that God is not the author of sin and unbelief'. Throughout his magisterial study, De Verkiezing Gods, Berkouwer comes back to this 'essential asymmetry', as central to understanding not only the Canons of Dort but also Reformed theology (see Berkouwer 1955: 201, 204207, 213, 222-224, 230-231,238, 248; 1960: 172, 175-178, 182, 189-190, 197-198, 201). He concludes: 'It is certainly not Reformed theology that feels called upon to protest against the "essential asymmetry". It is, rather, one of its most important characteristics that it emphatically affirms this asymmetry' (Berkouwer 1955: 213; 1960: 182). Berkouwer derives this expression of 'essential asymmetry' from Gérard Philips, the Belgian Catholic ecclesiologist, and key drafter of Vatican II's Lumen Gentium, who, according to Berkouwer, 'sees in it a mark of Roman Catholic theology' (Berkouwer 1955: 213, n. 34; 1960: 182, n. 16). There is a definite point of convergence here, he rightly insists, regarding the Reformed view as expressed by the rejection of 'the eodem modo in the Canons', on the one hand, and 'the Roman Catholic doctrine of election', on the other (Berkouwer 1955: 234; 1960: 198). Regarding the Catholic doctrine of election, suffice it to note here the essential asymmetry in Aquinas's thought: 'The causality of reprobation differs from that of 
predestination. Predestination is the cause both of what the predestined expect in the future life, namely glory, and of what they receive in the present, namely grace. Reprobation does not cause what there is in the present, namely moral fault, though that is why we are left without God. And it is the cause why we shall meet our deserts in the future, namely eternal punishment. The fault starts from the free decision of the one who abandons grace and is rejected, so bringing the prophecy to pass, Your loss is from yourself, $O$ Israel [Hosea 13:9]' (Aquinas, STh, I.23, a. 3, Reply to Objection 2). Of course this does not mean to deny that they differ significantly in their doctrine of predestination on 'the question whether God's eternal resolve of Predestination has been taken with or without consideration of the merits of the man (post or ante praevisa merita)' (Ott 2018: §12.2.a). Berkouwer issues 'a warning for anyone who wishes to take the essential asymmetry seriously' that the 'connection between asymmetry and praescientia is nothing but a false solution' (1955: 236; 1960: 200). Focusing on the Reformed view, Berkouwer explains:

The Canons of Dort speak of election and rejection when opposing the Remonstrants [see Dennison 2014: 41-44] (CD, I). When in the Canons and other confessions [e.g., Belgic Confession of Faith, the Westminster Confession of Faith], and also in reflection upon dogmatics, we repeatedly meet with these two words beside one another, we could get the impression that we are confronted with an obvious duality of two symmetrical 'decrees' of the divine predestination, decrees of the same structure as a Yes and No, side by side as predestination ad vitam and ad mortem. What does this conjunction 'and' mean between these words? Is election always conjoined with the word 'rejection', which we also encounter so often in Scripture? Does the confessional manner of speaking of rejection find its origin in the logical conclusion that election implies rejection? According to the 'logical' paradigm, the doctrine of double predestination would then be described as a reference to God's absolute apriori sovereignty before which man can only bow and keep silent.

Predestination would then be the general concept, and the two decrees of election and rejection would stand side by side as subordinates of the one denominator (predestination) of the divine prae in two different directions. Frequently the Church's doctrine of election was interpreted as such a transparent double predestination, and for that very reason people left her forever. And often fervent contention arose this very point. It seemed as if it was no longer possible to interpret the content of double predestination in more than one way. It ['equal symmetry'] became a traditional characterization which embodied everything that criticism wanted to bring up against the Church's doctrine of election (Berkouwer 1955: 201-202; 1960: 172-173).

According to Berkouwer, 'the doctrine of God's election ... is not a decretum absolutum, abstracted from Jesus Christ'. We cannot separate God's decree of election from his love and grace in Jesus Christ, God's Yes to man, of 
affirmation. In this light, we can understand why Berkouwer then asks about God's No to man's life of sin in history and therefore his judgment as an 'act of God in history', as a reactive deed, a holy, divine answer to the sin of man' (Berkouwer 1955: 215; 1960: 184). The crucial question then arises: 'Is it still necessary to speak of rejection after discussing the election in Christ?' (Berkouwer 1955: 200-201; 1960: 172). Yes, although there is no preterition there is still damnation. 'Mortal sin is a radical possibility of human freedom, as is love itself. It results in the loss of charity and the privation of sanctifying grace, that is, of the state of grace. If it is not redeemed by repentance and God's forgiveness, it causes exclusion from Christ's kingdom and the eternal death of hell, for our freedom has the power to make choices for ever, with no turning back' (Catechism §1861). Indeed, Berkouwer asks 'whether God's rejection belongs, and can belong, to the kerygma of the Church. Is it possible to see God's rejection differently than as God's holy answer to human sin?' (Berkouwer 1955: 239; 1960: 202). Significantly, Berkouwer presses the point that this question 'is not one of a mere symmetry, but [rather] that God has loved the world (John 3:16)'. He explains in a crucial passage,

It is then no longer understood that God did not send the Son to condemn the world (John 3:17) but that the world should be saved through Him. This is the profoundest reason for rejecting parallelism. This rejection does not imply the triumph of a simple sort of universalism. Immediately after John speaks of the purpose of Christ's coming, he adds: 'He that believeth on him is not judged: he that believeth not has been judged already, because he hath not believed on the name of the only begotten Son of God' (John 3:18). He who contemplated and approaches the gospel from the point of view of symmetry can no longer understand that Christ has come to be a crisis in the world, but he can only see in Him the execution of the symmetrical decree. The gospel can be understood and preached only if balance, symmetry, and parallelism are excluded. And by that gospel, the Holy Spirit will 'convict the world in respect of sin, and of righteousness, and of judgments: of sin, because they believe not on me' (John 16:8) (Berkouwer 1955: 238; 1960: 201202).

Furthermore, the denial of parallelism or symmetry of election and reprobation is mainly about revealing 'the meaning of election without creating the tension between election and preaching'. One may add here: the tension between election and evangelization; or, as Dort stated it, proclaiming the gospel 'to all persons promiscuously and without distinction, to whom God out of His good pleasure sends the gospel'. This tension remains unresolved even in a theology of predestination that understands election and reprobation asymmetrically because in the background hovers a decretum absolutum, namely, the decree of preterition. Even in the latter theology there remains 'the aprioristic double decree with its two groups of human beings, each of which was the "object" of one decision within the two-fold decree. The two 
groups were the elect and reprobate, which were 'two groups, shut off from each other by a static objectification'. Hence, adds Berkouwer, 'The universal proclamation of the gospel could be accommodated to this notion of 'two groups of human beings' only via a contrived dogma' (Berkouwer 1974: 139; 1977: 99-100). Berkouwer continues: 'This is why we ought not be seduced into thinking - in view of election-of two separate groups of people. The Bible does not present us with two classes of people, but only one, the sinners who are called to salvation' (Berkouwer 1974: 127; 1977: 95).

\section{Conclusion}

In conclusion, confessional Catholicism sides with the Synod of Dort in the rejection of the parallelism or symmetry of election and reprobation and argues that there is an 'essential asymmetry' at the heart of the doctrine of divine election. Confessional Catholicism goes further than Dort in holding that the point at issue about election is not one of a 'mere symmetry', but rather it is, chiefly, the point that 'God has loved the world (John 3:16)'. In this understanding, confessional Catholicism sides also with Berkouwer because he is right that the deepest reason for rejecting parallelism, including the parallelism of positive predestination and negative reprobation (i.e., preterition), is that God did not send the Son to condemn the world but rather that the world should be saved through him (John 3:17). Preterition is a theologically problematic notion, according to Catholicism, that seems to lead to the denial of the following: the sufficiency of Christ's atoning work for all men, the universality of God's salvific will (1 Timothy 2:4-6), contradicting the justice of God as well as man's freedom (Ott 2018: 245).

Preterition, or unconditional negative reprobation, seems to imply the idea of an abstract, merciless, and loveless sovereign decree; it is in contradiction with the Scripture that teaches that because of his great love for us 'God is rich in mercy' (Ephesians 2:4), that 'he was reconciling the world to himself in Christ' (2 Corinthians 5:19), and that it is precisely the coming of Christ, the one and only Son of the Father, sent by the Father, which is the revelation of God's love (1 John 4:9). 'For the Son of God, Jesus Christ, whom we proclaimed among you ... was not Yes and No, but in him it is always Yes. For all the promises of God find their Yes in him. That is why it is through him that we utter our Amen to God for his glory' (2 Corinthians 1:19-20).

Berkouwer is also right that 'this rejection [of parallelism] does not imply the triumph of a simple sort of universalism' (Berkouwer 1955: 238; 1960: 201-202). Confessional Catholicism holds that to avoid universalism the distinction between the antecedent and consequent will of God, as well as the corresponding distinction between sufficiency and efficacy of the atoning work of Christ, must be used in explaining the difference between the universal salvific will of God and its efficacy. In this way, we can give an account 
of the 'kerygmatic universality' of the free and general offer of the Gospel that reveals God's universal salvific will for all men (1 Timothy 2: 4-6) without collapsing into universalism.

\section{Bibliography}

(Thomas) Aquinas, Summa Theologia. Online: https://www.newadvent.org/summa/.

Augustine (1966) On the Catholic and Manichean Ways of Life. Washington, DC: Catholic University of America Press.

City of God. Online: https://www.newadvent.org/fathers/1201.htm.

Bavinck H (1897) Gereformeerde Dogmatiek, II. Kampen: J. H. Kok. Translated by Vriend J as Reformed Dogmatics, God and Creation, volume 2. Edited by Bolt J. Grand Rapids, MI: Baker Academic.

(1897) Gereformeerde Dogmatiek, III. Kampen: J. H. Kok. English translation (2004) Reformed Dogmatics, Sin and Salvation in Christ, volume 3, ed. Bolt J, trans. Vriend J. Grand Rapids, MI: Baker Academic.

Beatrice PF (2013) The Transmission of Sin: Augustine and the Pre-Augustinian Sources, trans. Kamesar A. Oxford: Oxford University Press.

Beeke JR \& Ferguson SB (eds) (2006) Reformed Confessions Harmonized, with an Annotated Bibliography of Reformed Doctrinal Works. Grand Rapids, MI: Baker Books.

Berkouwer GC (1955) De Verkiezing Gods. Kampen: Kok; English Translation: Divine Election (1960) trans. by Bekker H. Grand Rapids, MI: Eerdmans.

(1960) De Zonde II, Wezen en Verbreiding der Zonde. Kampen: Kok; English Translation is a translation the two Dutch volumes in one volume. Sin, (1971) trans. by Holtrop PC. Grand Rapids, MI, Eerdmans.

(1974) Een Halve Eeuw Theologie: Motieven en Stromingen van 1920 tot Heden. Kampen: J. H. Kok. Trans. and ed. by Smedes LB as A Half Century of Theology: Movements and Motives (1977) Grand Rapids, MI: Eerdmans.

Blocher H (1997) Original Sin, Illuminating the Riddle. Grand Rapids, MI: Eerdmans. Catechism of the Catholic Church. http://www.vatican.va/archive/ENG0015/_INDEX.HTM. Couenhoven J (2005) St. Augustine's Doctrine of Original Sin. Augustinian Studies 36(2): 359-396.

Crisp OD (2006) Federalism vs Realism: Charles Hode, Augustus Strong and William Shedd on the Imputation of Sin. International Journal of Systematic Theology 8(1): 55-71.

Cunningham W (1967) The Reformers and the Theology of the Reformation. Edinburgh: Banner of Truth.

Dennison Jr. JT (ed) (2010) Reformed Confessions of the 16th and 17th Centuries, volume 2, 1552-1566, compiled with introduction by Dennison, Jr. JT. 
Grand Rapids, MI: Reformation Heritage Books. Belgic Confession of Faith, 424-449, Article 16.

(2014) Reformed Confessions of the 16th and 17th Centuries, volume 4, 1600-1693, compiled with introduction by Dennison Jr. JT. Grand Rapids, MI: Reformation Heritage Books. The Canons of Dort (1618-1619).

Denzinger H (2102) Compendium of Creeds, Definitions, and Declarations on Matters of Faith and Morals, Latin-English, ed. Hünermann P, 43rd edition, English edition, eds. Fastiggi R and Englund Nash A. San Francisco: Ignatius Press.

Di Noia, OP, JA (2017) Not 'Born Bad': The Catholic Truth About Original Sin in a Thomistic Perspective. The Thomist 81: 345-59.

Echeverria E (2016) Divine Election: A Catholic Orientation in Dogmatic and Ecumenical Perspective. Eugene, OR: Pickwick Publications.

Grisez G (1983) The Way of the Lord Jesus, volume 1: Christian Moral Principles. Chicago: Franciscan Herald Press.

Hahn S (2017) Romans, Catholic Commentary on Sacred Scripture. Grand Rapids, MI: Baker Academic.

Murray J (1959) The Imputation of Adam's Sin. Phillipsburg, NJ: Presbyterian and Reformed Publishing.

Oakes SJ, ET (2016) Evolution and Original Sin, 92-137. In A Theology of Grace in Six Controversies. Grand Rapids, MI: Eerdmans, 2016.

Orr J (1901) Progress of Dogma. Old Tappan, NJ: Fleming H. Revell.

Ott L (2018) Fundamentals of Catholic Dogma. Trans. by Patrick Lynch, ed. in English by Bastible JC, fully revised and updated by Fastiggi R. Oil City, PA: Baronius Press.

Pascal B (1995) Pensees. London: Penguin Classics.

Ridderbos H (1973) Paulus, Ontwerp van Zijn Theologie. Kampen: Kok; English Translation (1975) Paul: An Outline of His Theology, trans. by De Witt JR. Grand Rapids, MI: Eerdmans.

Vermigli PM (2018) Predestination and Justification, Two Theological Loci, transl. and ed. by James III FA. Moscow, ID: Davenant Press.

Weber O (1995) Grundlagen der Dogmatik. I. Neukirchener Verlag.

Wesley J (2014) Free Grace. In The Works of John Wesley, volume 3: Sermons 71-114. Grand Rapids, MI: Zondervan.

Williams NP (1927) The Ideas of the Fall and of Original Sin: A Historical and Critical Study. London: Longmans, Green. 